\title{
Victimological Approaches to Crime of Rape in Indonesian Criminal Justice System
}

\author{
Khudzaifah Dimyati1 ${ }^{1}$ Angkasa ${ }^{2}$ \\ 1 Faculty of Law, University of Muhammadiyah Surakarta, Indonesia. \\ ${ }^{2}$ Faculty of Law, University of Jenderal Soedirman Purwokerto, Indonesia. \\ * Corresponding author E-mail:kd255@ums.ac.id
}

\begin{tabular}{l} 
ARTICLE INFO \\
\hline Keywords: \\
Rape; Criminal Justice \\
System; Legal Protection; \\
Victimology \\
How to cite: \\
Dimyanti, K., Angkasa. \\
(2018). "Victimological \\
Approaches to Crime of \\
Rape in Indonesian \\
Criminal Justice System," \\
Hasanuddin Law Review, \\
4(3): 366-376 \\
DOI: \\
10.20956/halrev.v4i3.1292 \\
\hline
\end{tabular}

\begin{abstract}
Neglect of rape victims in the Indonesian Criminal Justice System implicates at least two things; first, the victim does not receive legal protection, and second, the decisions of judges do not fulfill the sense of justice. Neglect of victims in the Criminal Justice System cannot be separated from the theory, doctrine and legislation, especially criminal law or the Penal Code, Criminal Procedure Code and the Corrections Act, which is oriented merely to the perpetrators (criminal oriented) instead of victims (victim oriented). Regarding the conditions above, this study was intended to provide a solution of the problems so that victims in the Criminal Justice System obtain legal protection and the decision of judges could fulfill the sense of justice.
\end{abstract}

Copyright (C) 2018 HALREV. All rights reserved.

\section{Introduction}

The position of rape victims in the Criminal Justice System has not received proportionate place and often becomes the "forgotten". ${ }^{1}$ Then this has two fundamental implications: the absence of legal protection for victims; and no judges' decision that fills the sense of justice for victims, perpetrators and society.

Philosophically criminal law serves to protect the legal interests of the acts of rape with penal sanctions which are sharper than other legal sanctions. However, the explanation of these philosophical bases in some phases is not aligned. Formulations of crime contained in the substantive criminal law, such as in the Book of Criminal Law (Penal

1 Victims of crime as told by Shapland be "Forgotten man" or less considered the role of victims in criminal proceedings. See more: Shapland Joanna, Jon Willmore, Peter Duff, 1985, Victims In The Criminal Justice System, Series Editor: AE Bottons, Published by Gower Publishing Company Limited, Gower House, Croft Road, Aldershot, Hant Gu 3 HR, England. p. 1 and p. 496. See also: I.S. Susanto, 1995. Criminology, Faculty of Law at Diponegoro University, Semarang, p. 90. 
Code), do not fully accommodate these goals through formulations prohibited acts along with the threat of criminal sanctions for perpetrators. Similarly, the formulation of the formal criminal law (criminal procedure) as stipulated in the Law no. 8 of the Criminal Law of 1981 (Criminal Procedure Code), legal protection for victims is still far from being fair. ${ }^{2}$ The formulation of legal norms penitentiary, as stipulated in Law No.12 of 1995 on the Correctional is more oriented to the management of coaching inmates who loaded the attention and respect for human rights for prisoners, as recommended by the United Nations through the instruments of the Standard Minimum Rulers. Similar case is visible in the empirical level (law in action), which emphasizes more on the perpetrator (criminal oriented) instead of the victim.

However, when assessed with Victimology, the process of handling criminal cases in the Criminal Justice System under the criminal law and criminal procedural law in Indonesia has not been concerned with the law protection of the victim which in turns may cause structural victimization to the victim. It is resulted in the absence of legal protection of the status and dignity of the victim as an individual. The proceedings in the Criminal Justice System trigger stigmatization to victim's livelihood. In other words, the victims usually experience double victimization, receiving social cultural political sanctions from the community.

Neglected victims in the judicial process elements tended to be neglected during the court's decision which should fulfill the sense of justice for perpetrators and the society. In many criminal cases, the victims can act in various degrees of innocence until the process of investigation shows that the degree of perpetrator's wrongdoings finally being revealed. Such conditions have been presented to show the absent presence of victim in a fair situation within Criminal Justice System. The logical consequence attached to victim such as dissatisfaction with the implications of justice is essentially a reflection of the disparity view toward unfair criminal law.

Unequal attention to the position of victims in the Criminal Justice System cannot be separated from the norm of positive law that is based on criminal law policy and political crimes, as well as source of legal doctrine. Attention orientation in criminal law that includes material criminal law, formal criminal law and criminal law implementation is more oriented toward the importance of perpetrator instead of the victim.

Based on the background above, in the writers' opinion, the paradigm within criminal law has to be changed. The orientation is directed not only to the perpetrators but to the victims as well, in a balanced manner. In the literature review of victimology by Schafer (1968), it is referred as the criminal-victim relationship.

Referred to the above background, the attention of the criminal law is to the evil deeds, fallacy, victim and criminal. ${ }^{3}$ By implementing victimology paradigm, it seems that sense of justice within the criminal law could be achieved. This concept is being reviewed and developed in many studies to investigate the position of victims in the Criminal Justice System.

2 Criminal Procedure Code contains 22 chapters consisting of 286 chapters recognized as a masterpiece or a "master piece" of Indonesia. When viewed the principles contained in it loaded with the protection of human dignity as a reflection of respect for human rights as seen in consideration and explanation of these laws. However, when observed, it tend center more on legal protections for criminal suspects as well as the defendant began the process of investigation, prosecution and judiciary

3 Iswanto. (2000). Korban Tindak Pidana Sebagai Masalah Pokok Hukum Pidana Seyogyanya Diadopsi Dalam Hukum Pidana Positif Indonesia. Speech for Inauguration of Associate Professor in Law in the Faculty of Law of Unsoed Purwokerto, p. 25 
Based on previous reasoning, it is significant to conduct a study on the victim's position in the criminal justice system. Estuary recommended a model of the victims in a fair position in the Criminal Justice System that would achieve sense of justice as the nature of the establishment of fair norm. This study focuses on victims of rape who are subject to the provisions of Article 285 of the Penal Code. The definition of rape in the provisions is "whoever by force or threat of violence forcing a woman to have sex with her outside of marriage."

There are three main reasons underlying the chosen victim of the crime of rape in this study. First, the magnitude of suffering and/or the psychological breakdown experienced by rape victims throughout their lives. Second, many victimology literatures mentioned that the victim may accelerate the crime of rape. Level of the victim role here can refer to the concept of Victim Precipitation (VP), a conception that explains that in general in each case contained elements of crime of rape for the rape victim participation. ${ }^{4}$ Amir's study 5 shows that victim was viewed being participated in the crime violation. Based on the concept mentioned above, the present research investigated whether such case was considered to be the basic consideration when judges decide a case. Third, based on the characteristics inherent in criminal cases of rape, the results of the study could be recommended as the basic model for the policy change in fulfilling the equal and fair position of a victim as an individual in the Criminal Justice System.

In addition to the three reasons above, criminal statistics index by the Indonesian Police Headquarters reported that there were 1267 criminal cases of rape throughout the year of 1999. This means that there were three cases of rape on average in Indonesia every day. The predicted number of unrevealed cases tended to be higher in reality because there were cases that were not reported as a dark figure (dark numbered) because of several factors, especially the reluctance of victims to report due to embarrassment and other threats. Nowadays the position of victims in the Criminal Justice System has not been placed proportionately and fairly. They even tend to be forgotten that generate a sense of dissatisfaction, especially for victims. Ellias even viewed that the victim becoming a victim for the second time in the Criminal Justice System by using various terms such as second victimization, twice victimized, and double victimization. ${ }^{6}$ Ellias argued that victims usually encounter neglect from the society and neglects on their victimization, and criminal justice system imposes a second victimization to the victim. He stated that today victim is seen at best as the forgotten individual of the system and at worst as being victimized twice, the second time by the system itself. Furthermore, he asserted that victims sustain cost from at least two different sources. In this sense, they have to face double victimization.

This is being considered because in addition to victims suffering a loss and/or suffering including loss of material, physical injury or prolonged psychological suffering, as often happens to rape victims, victims in many actual events have been credited for helping the police to uncover a case through reports and administration of information on the

\footnotetext{
Atmasasmita, R. (1995). Kejahatan Kesusilaan dan Pelecehan Seksual Dalam Perspektif Kriminologi dan Viktimologi dalam Pelecehan Seksual. Suparman Marzuki (ed). Fakultas Hukum UII Yogyakarta.

Amir, M. (1971) Patterns in Forcible Rape Chicago University of Chicago Press, p. 83.

6 Elias, R. (1986) Community Control Criminal Justice and Victim Services dalam Fattah Ezzat A 1986 From Crime Policy To Victim Policy Reorienting the Justice System The Macmillan Press Ltd Houndmills Basingstoke Hampshire RG21 2XS and London.
} 
characteristics of perpetrators.

Neglect of victims in the Criminal Justice System tends to implicate at least two things. First, the victim did not receive legal protection, and second, the decision of the judges tends to be less fulfilling sense of justice. Neglect of victims in the Criminal Justice System cannot be separated from the theory, doctrine and legislation, especially the Penal Code, Criminal Procedure Code, and the Corrections Act, which is being oriented to the perpetrators (criminal oriented) instead of the victim (victim oriented).

Based on the above conditions, this study was intended to answer those problems so that victims in the Criminal Justice System deserve more attention than the perpetrator. It is hoped that the implication of the study could attain victim's law protection and decisions of the judges could fulfill sense of justice.

Hence, the starting point is by changing the orientation of the criminal law which was originally focused on the perpetrators shall be shifted to be oriented toward a balanced orientation between perpetrators and victims (criminal-victim oriented). The change of orientation implicates fundamental change in criminal law as a whole that starts from the theory, doctrine until primary legislation of the Criminal Code, Criminal Procedure Code, and the Corrections Act, and the estuary also has implications on the Criminal Justice System.

Criminal law theory and doctrine that had been familiar with criminal law issues merely include three things as stated by Packer including the crime (offense), blame (guilt) and criminal (punishment). ${ }^{7}$ The previous three are completed with the fourth element, that is concerning with victims to highlight their needs. Thus, the main problem in the criminal law will cover the four previous issues.

At the level of legislation, the implementation of perpetrator-victim orientation in a balanced way will implicate changes and/or adjustment of the principles and/or the formulation of the provisions of legislation in the preamble, the articles and explanations. Several aspects that need to be changed and/or adjusted include the following. First, the formulation of the crime of rape which currently accommodates the interests of the victims does not appear to be the prime concern, especially on the understanding of sexual intercourse and punishment. The theory adopted in this change includes the theory of the sociology of law from Quinney, "The Sociology Theory of Interest".

Second, the rights of victims as explained in legal protection in the Criminal Procedure Code have not been stated clearly and even intangible. Deductive upcoming change adopted in this case is the General Principles of the Magna Charta For Victim and the Declaration of Basic Principles of Justice for Victims of Crime and Abuses of Power. To support this theory in an effort to provide a fair place between the victim and the perpetrator is also equipped with Aristotle's theories of commutative justice which emphasizes much on the victim as an individual. It also fits with one of the principles in criminal law that is equality before the law implying that everyone (including victims and offenders) has equal status before the law.

Changes of this kind of orientation in the opinion of the writer can be said of the change or to borrow a phrase occured in Fritjof Capra in the criminal law paradigm. Told that change is not replacement, because the elements of the old paradigm is still partially used, and only added to the other elements, does not radically change the whole element. 
Third, the model of punishment is currently not taking into account the involvement of victims. The theory of the Criminal-victim Relationship by Schafer was born, grown and thriven to flourish the discipline of Victimology so as to support the underlying theory to account for the involvement of victims in criminal imposition. The theory essentially explains that a crime occurred because of the relationship between victims and perpetrators. Amir's study in rape cases showed that the perpetrators should not be viewed as the sole cause of the crime and the victim should not be viewed as a holy person who is innocent and passive.

It is important to consider the imposition of the victim in the criminal aspects as referred to the opinion of Separovic. ${ }^{8}$ The concepts in the study of victimology known as victim precipitation are related to the degree of accountability as well as victims of victimization. To support the theory of the Criminal-victim relationship in criminal imposition of the model, this study also used theory of distributive justice (justitia distributiva) from Aristotle.

Fourth, relating to the need for restitution to be applied in addition to imprisonment. Apparently giving restitution can fulfill sense of justice more to victims of crime rather than merely the imposition of the perpetrator. Restitution paid to victims, especially victims of rape who suffered material losses and/or physical pain and severe psychologies breakdown, can be used to alleviate their loss and/or suffering.

Fifth, if restitution is not optimal then compensation can be provided alternatively or cumulatively with compensation to the victims. Compensation based on the results of several expert studies show great benefit to the victim because as proposed Doerner and $\mathrm{Lab}$, that compensation in the form of a sum of money (monetary) can be perceived as a drug of all diseases (panacea).

Accordingly, this paper describes and explains the position of crime victims of rape in the Criminal Justice System using Victimology perspective; and explores a model that can support the imposition of criminal court decision that fulfills the sense of justice.

\section{Method}

This is descriptive research which probed the position of crime victims of rape in the Criminal Justice System. The method used in this study was juridical-sociological (sociolegal research) with the type of qualitative research. The qualitative research types was chosen to be used in order to reveal and obtain deep and detailed meaning of the object of research from many sources.

In an effort to get information with wide variety of data, this study employed triangulation of data sources on the position of victims in the Indonesian Criminal Justice System. The triangulation exemplified variety of relevant sources in the form of primary data and secondary data sources (non-human sources), as well as data being reflected in the situation of social institutions. Primary data were elicited from a number of sources including victims of rape (including families of victims), police, prosecutors, judges, lawyers, psychologists, ex-convict perpetrators of rape, and women's activist. Secondary

${ }^{8} \mathrm{Z}$ vonimir Paul Separovic stated: Findings and empirical evidence about the victim's role may contribute to a better understanding of criminal case. Law enforcement agencies and court must thoroughly investigate the role of victim, and some legislative changes seem to be desirable in order to achieve full understanding of the case, to determine whether for instance provocation by victim was sufficient either to reduce or to eliminate culpability altogether (Zvonimir Paul Separovic, 1985, Victimology Studies of Victims, Publishers "Zagreb", Samobor-Novaki by Pravni Fakultet, Zagreb. p.12.) 
data were obtained from the legislation, especially the Penal Code, Criminal Procedure Code and the Corrections Act, literature, documents (court file), and the results of research related to the object of this research. The social situation included the description of a state where the space of a social situation was carried out; the actors in social situations, including the inherent characteristics of interviewees (such as status, gender, age, ethnicity, economic class, political orientation, and culture).

These aspects were examined in an attempt to find answers to research problems including loss and/or the suffering of victims of crime; normative provisions in the Penal Code, Criminal Procedure Code and the regulations implementing the substance of the regulations related to the crime of rape; implementation of the position of the victim in the Criminal Justice System; opinions of practitioners, victims and/or families of victims of legal protection for victims of crime that fulfill the sense of justice; model of legal protection for victims of crime in the Criminal Justice System; and punishment model that considers the elements of crime victims in the imposition of conditions to fulfill the sense of justice.

Data collecting in this study involved triangulation methods including relevant methods such as interviews, observation, and literature review in accordance with the types of data sources needed. Research location was specified in the Banyumas region, Central Java, Indonesia. Banyumas was chosen due to significant number of rape victims in the past few years compared to other areas.

The samples of the research related to the selection of certain speakers and social situations which were assumed to provide steady and reliable information about the elements covered in the focus of research. The observed social situations included the ones which were summarized into information on the aspects covered in the focus of the research. As an initial sample, the observed social situation was the one that was simple enough to be observed and relatively easy to be accessed. Situation was also captured from the room situation in the police investigation, attorney, and the court with all activities in the room. The selection of the sample, in the form of resource or key persons, was developed through the principle of snow balls and the options expired after a sample had the indication of "no rise" variations or new information related to research materials. Based on the snow balls principle above, then the writer selected a number of key persons from various circles, as already outlined in the sample of interviewees (90 persons).

The collected data were analyzed qualitatively by sequential induction conceptualization which was employed as a research approach to build concepts, hypotheses and theories. To interpret higher level of abstraction into the form of statements of theoretical significance, this research was confronted firstly with Victimology and the theory of criminal law so that it would describe the position of victims of the crime of rape in the Criminal Justice System, and the model which fulfills the imposition of criminal sense of justice.

\section{Legal Status of Victims in the Indonesian Criminal Justice System}

The position of victims in the Criminal Code seems not to be optimal compared to the perpetrator. ${ }^{9}$ This can be observed by the following explanation. First, the Penal Code

9 Not optimal in the Criminal Code actually means there is concern for the victims, but according to the opinion of the writer still there are some aspects of the interests of victims that have not been accommodated. Attention of the Criminal Code of the victims looked as Barda Nawawi Arief opinion stating that "In criminal law the 
has not been explicitly formulated in a clear term and it had not directly provided legal protection to victims such as in the rape case which shall consider the effect of the imposition of criminal offenses against the victim or victim's family. Criminal Code has not defined types of criminal restitution (compensation) which is actually very beneficial to victims and/or victim's family. The formulation of the articles of the Penal Code focuses solely on the definition of crime, and criminal accountability.

Second, the Penal Code adopted the neoclassical school, which, among others, receives entry into force of a mitigating circumstance for the perpetrators of criminal acts involving aspects of physical, mental and environmental. Similarly, allowing mitigating aspects of criminal offenses with some accountability in particular mental disabilities (insane), under age and so forth. The character of neoclassical school was reflected among others in the provisions of Article 44 of the Penal Code. Based on neoclassical school and the provisions of Article 44 of the Criminal Code, under certain circumstances a person may be a criminal if not sentenced to qualify as provided in Article 44 of the Penal Code, for example, the respective insanity or other mental disabilities. Reflected on these conditions, it can be criticized by a question: "what is the attention of the criminal law towards the rape victim when the crime is acted by an individual that cannot be accounted for due to his psychological disabilities?" No conviction of a person with psychological disabilities committed the crime because it cannot be accounted for in an actor's perspective, and the purpose of punishment cannot be justified, but in the perspective of the victim it could be realized. Victims who experience psychological breakdown and/or suffering should continue to have access to justice-even though the perpetrators cannot be convicted as guilty--for instance in the form of compensation. In such cases it could be described that as an important part of justice system, the victim has been forgotten in the Criminal Justice System.

Based on previous exposure, two things could be inferred as follows. First, the Penal Code should explicitly define the form of legal protection for victims in a more concrete example in the case of rape. It shall consider the effect of the imposition of criminal offenses against the victim or victim's family. Penal Code also needs to formulate a type of criminal restitution (compensation) that would be very beneficial to victims and / or victim's family. Second, the Criminal Code needs to provide access for victims to obtain justice from the perpetrators of rape crime related to the provisions of Article 44 of the Penal Code. Justice can be realized in the form of compensation. The International Covenant on Civil and Political Rights has an instrument known as the Optional Protocol to the International Covenant on Civil and Political Rights. Reflection of players' rights protection (Article 50 and Article 68 of the Criminal Procedure Code), in line with The Universal Declaration of Human Rights follows the International Covenant on Civil and Political Rights and its Optional reflected in Article 9 and Article 14 International Covenant on Civil and Political Rights. 10 The principles reflected in Article 9 International Covenant on Civil and Political Rights, among others, as follows:

1) No one has taken their liberty arbitrarily unless the proposed basis and in accordance with statutory procedures.

2) Any person at any place of detention could soon be submitted to and reviewed by a judge. During the wait for the examination in court then said that a temporary

current positive, more is the protection of victims' protection abstract" or "indirect protection". It means the existence of various criminal acts in the formulation of legislation so far, means that essentially had no legal protection and victim rights. See: Barda Nawawi Arief, (1998), Some Aspects of Policy and Development of Criminal Law Enforcement, Citra Aditya Bakti, Bandung, p. 55

10 Adji, I.S. (1998). Penyiksaan dan HAM Dalam Perspektif KUHAP. Jakarta: Pustaka Sinar Harapan, p. 36. 
detention is an exception.

3) People arrested/held the authority to submit to the court, so that these courts in the not so long (without delay) may determine the legitimacy of the detention and release if the detention is deemed invalid.

4) Every person who becomes the victim of unlawful detention has the right to obtain compensation.

Similarly, the provisions of Article 14 International Covenant on Civil and Political Rights which seems to have adopted provisions in the Criminal Procedure Code provisions and interest-oriented actors. The provisions referred to are as follows:

1) Allegations set forth in a language that needs to be understood by the accused about the nature and causes of the relevant charges.

2) Adequate preparation in time to conduct his defense and rights associated with legal counsel (right to communicate).

3) Inspection as soon as possible (without any delay).

4) Trial and to conduct the defense of himself or through an advocate, informed him of his rights when he was not accompanied by an advocate, obtain legal assistance, especially if he is less able to obtain legal aid.

5) Check (to examine) the witness to a charge of witnesses attending a charge or a de charge.

6) Getting an interpreter, if he does not understand the language used in court.

7) The right not to incriminate himself (right of non-self-incrimination).

Based upon the above explanation, it can be recommended that the Criminal Procedure Code in the translation of consideration through the provision of article should fairly paid balance attention to aspects of justice and the protection of the dignity both of victims and perpetrators

This study is considering designing a concept model to place fair and balance imposition of criminal victims and offenders in the hope of supporting the decision of the judges who shall fulfill sense of justice. The concept of this model is designed based on previous analysis. The present writers come to the following concept of the model in the following chart and detailed explanation:

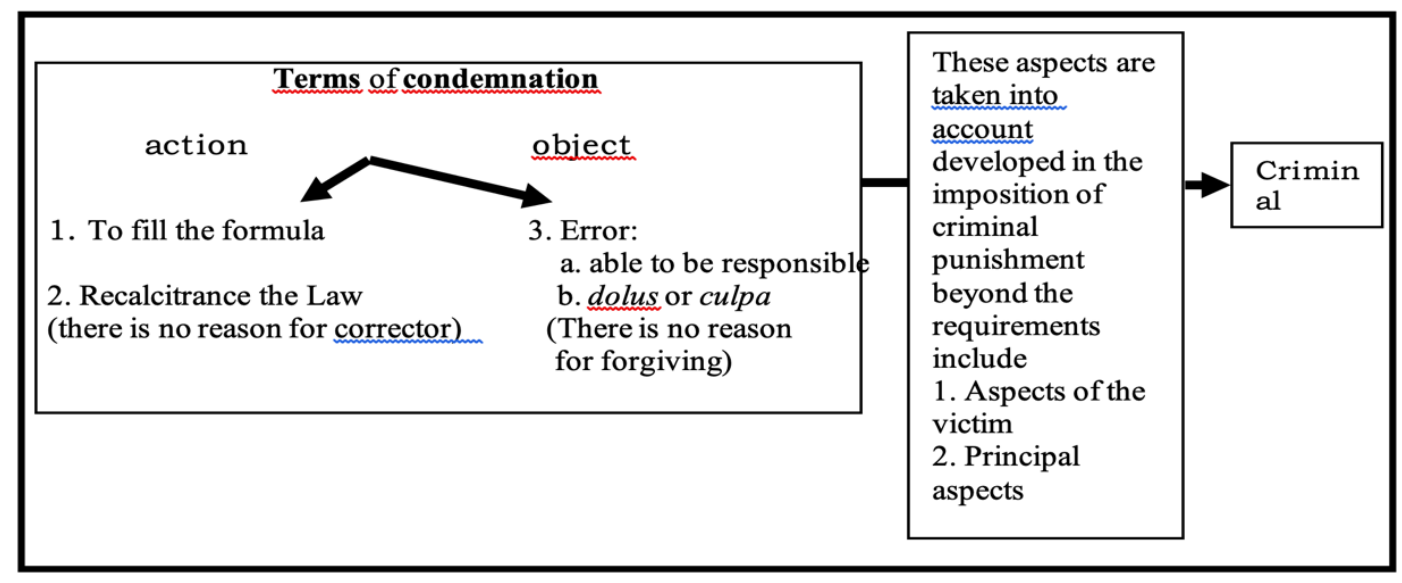

The model could optimally fulfill sense of justice in which victims' rights are taken into consideration in these convictions. Elements of taking victim into account should be considered in the proper punishment for the sake of justice. The present writers thought that they are in line with the arguments and opinions of Victimologs. Victimolog view 
that the terminology in criminal law that had been used to describe the perpetrators in terms of accountability (responsibility), negligence (culpability), the fault (guilt) could be borrowed as well as applied for the sake of victim's neglected rights. This means that victims can be positioned in the liability, negligence or error. This view as an effort to correct orthodox views which is considered unbalanced, unfair, as well as oriented merely to the perpetrator (criminal oriented).

These three aspects are indeed known in the discussion of victimology. In terms of accountability, among others, written by Schafer that the victim has the functional responsibility to actively avoid becoming a victim and not to provoke and to contribute to the commission of a felony.

Victim provocation or contribution to the occurrence of victimization in perspective of victim victimology often referred to as precipitation (VP) which relates to the degree of accountability as well as victims of victimization. Referring to the conception of VP then it appears that the victim may have a significant contribution to the occurrence of victimization and are appropriately accountable for the sake of justice for the victim (shares responsibility) and considered by the judge in the imposition of criminal liability.

Based on these conditions, many authors recommend the concept of model by considering the imposition of criminal aspects of the victim and perpetrator in order to support fair verdict judgment that fill the sense of justice. The model in question is as follows. First, the imposition of criminal punishment must be eligible to be considered as acts and elements. Element of "action" includes actions that fill the formulation of laws and acts that are against the law and no justification. Element of "people" related to any errors which include the ability of perpetrators to be responsible and the inner relationship between the perpetrator and the act and the consequences in the form of intention (dolus) or negligence (culpa) and there is no reason for forgiving.

Second, if the conditions are met then the punishment can be carried out to punish the perpetrators. However, before the imposition of the criminal, there are two aspects that must be considered including the aspects of victim and perpetrator. Aspects of the victims include psychological breakdown and / or suffering resulting from criminal acts that happen to her/him, as well as the degree of error in the crime victim (victim precipitation). Principal aspects to be considered include the attitude and behavior toward the victim after the crime, personality, and a commitment to settle the case.

Third, after the requirements are met and the punishment aspects of the victim and the perpetrator are considered, then the punishment can be decided. The type and duration of the imposed penalty was correlated to the fulfillment of the terms of punishment and the consideration of aspects of victim and perpetrator.

Of the several types of criminal and penal institutions that exist, in our opinion, still needs to be added. The writers recommend this concept model to any type of criminal restitution. Restitution should be incorporated in the Criminal Justice System, with the consideration that restitution is a criminal institution that can provide benefits to victims, perpetrators, the state and society.

In addition to restitution, compensation seems to be used as an alternative system for the government in the framework of rehabilitation for damages and/or suffering to help its citizens who become victims of crime. The authors suggest an alternative system because the main system can be used to provide assistance to victims through restitution. If the refunds due to several factors are hindered or not optimal, the compensation program to be used alternatively or cumulatively with restitution 


\section{Conclusion}

Rape victims suffer losses, mental breakdown and/or suffering financially, physically, psychologically, and socially. Among many losses, psychological or mental breakdown is the heaviest. Although rape victims suffer financially, physically, psychologically, and socially, their position in the Criminal Justice System has been neglected. Estuary has less sense of justice perceived by the victim. This is due to the paradigm of substantive criminal law, criminal law, and the formal implementation of criminal law supporting the operation of Criminal Justice System which has been more oriented toward the perpetrator than the victim. It could be seen from: Embrace of the Criminal Code which, among others, neoclassical school received into force a mitigating circumstance for the perpetrators of criminal acts involving physical and mental environment. The Criminal Code is less optimal in accommodating the interests of rape victims.

\section{References}

Adji, I.S. (1998). Penyiksaan dan HAM Dalam Perspektif KUHAP. Jakarta: Pustaka Sinar Harapan.

Amir, M. (1971). Patterns in Forcible Rape. Chicago University of Chicago Press.

Arief, B.N. (1998). Beberapa Aspek Kebijakan Penegakkan dan Pengembangan Hukum Pidana. Bandung: Citra Aditya Bakti.

Atmasasmita, R. (1982). Strategi Pembinaan Pelanggar Hukum Dalam Konteks Penegakkan Hukum di Indonesia. Bandung: Alumni.

Atmasasmita, R. (1995). Kejahatan Kesusilaan dan Pelecehan Seksual Dalam Perspektif Kriminologi dan Viktimologi dalam Pelecehan Seksual. Suparman Marzuki (eds) Fakultas Hukum UII Yogyakarta.

Christie, N. (1986). The Ideal Victim dalam From Crime Policy To Victim Policy Reorienting the Justice System Ezzat A Fattah (ed). The Macmillan Press Ltd Houndmills Basingstoke Hampshire RG21 2XS and London.

Doerner, W.G. and Lab, S.P. (1998) Victimology. Edition 2 Indiana: Anderson Publishing Company.

Elias, R. (1986) Community Control Criminal Justice and Victim Services dalam Fattah Ezzat A 1986 From Crime Policy To Victim Policy Reorienting the Justice System The Macmillan Press Ltd Houndmills Basingstoke Hampshire RG21 2XS and London.

Gosita, A. (1993). Masalah Korban Kejahatan (Kumpulan Karangan). Jakarta: Akademika Pressindo.

Graborsky, P. (1987). Victims dalam The Criminal Injustice System Editor: George Zdenkowski Chris Rolands dan Richardson Pluto Press Australia.

Harding, J. (1982). Victims and Offenders: Needs and Responsibilities Bedford Square Press NCVO London UK.

Holman NAG (1976) Criminal Sentencing and Victim Compensation Legislation: Where is the Victim? dalam Victims and Society Emilio C Viano (ed). Visage Press Inc. Washington DC. 
P-ISSN: 2442-9880, E-ISSN: 2442-9899

Iswanto. (2000). Korban Tindak Pidana Sebagai Masalah Pokok Hukum Pidana Seyogyanya Diadopsi Dalam Hukum Pidana Positif Indonesia Pidato Pengukuhan Jabatan Guru Besar Madya dalam Ilmu Hukum pada Fakultas Hukum Unsoed Purwokerto. 